\title{
SCHLAP1 Gene
}

National Cancer Institute

\section{Source}

National Cancer Institute. SCHLAP1 Gene. NCI Thesaurus. Code C118202.

This gene is involved in the malignancy of prostate cancer. 